\title{
Occupational Health and Safety and Sustainable Development in Ghana
}

\author{
Kwesi Amponsah-Tawiah \\ Department of Organizational and Human Resource Management, University of Ghana Business School \\ P. O. Box LG 78, Legon, Accra, Ghana \\ Tel: 233-54-623-8672Ｅ-mail: kwesi.amponsaht@googlemail.com
}

Received: January 8, 2013

Accepted: February 26, $2013 \quad$ Online Published: March 14, 2013

doi:10.5430/ijba.v4n2p74

URL: http://dx.doi.org/10.5430/ijba.v4n2p74

\begin{abstract}
This paper examines the state of occupational health and safety in Ghana and the role it plays in the sustainable development agenda of the country. It reviews literature on the triple bottom line (people, profits and planets) and how they are affected by OHS policies and the effects of work related hazards on sustainable development. The paper observes the argument that there are three pillars of sustainable development; people, planet and profit. The paper also reveals that OHS has three pillars similar to sustainability; Economy, Environment and Society. It thus recommends that there should be sound OHS policies that will embrace sufficient environmental friendly programmes to ensure that the employees are safe and hence ensure sustainability.
\end{abstract}

Keywords: Occupational health, Safety, Sustainable development, Environment, Society, Economy

\section{Introduction}

Following the release of the Brundtland Report in 1987, concerns over sustainable development has assumed a much wider set of issues than previously thought. Previous literature on sustainable development has concentrated on the environment with great emphasis on ways of harnessing green technology for sustainable development. The changing nature of the world, corporate structures, marketing strategies and production processes poses more occupational health and safety issues of late. It thus appears that gains chalked in green technology and sustainable development stands the risk of being offset by costs of occupational health and safety diseases and hazards.

Existing literature has examined the role of occupational health and safety in varying facets (see for instance Cooper 1994; Zwetsloot \& Starren 2004; Adei \& Kunfaa, 2004; Amponsah-Tawiah \& Dartey-Baah, 2011). Unfortunately little has been written on the role of occupational health and safety to sustainable development. Studies exploring the role of occupational health and safety (OHS) on sustainable development are either fragmented or their relationships merely glossed over in an attempt to make arguments regarding OHS in a certain particular agenda. To date occupational health and safety has not attained a high profile in the sustainable development agenda particularly in Ghana where most people are engaged in primary industries such as agriculture, logging and mining. This paper therefore examines the state of occupational health and safety in Ghana and its place in the sustainable development agenda of the country.

\section{Occupational Health \& Safety}

Occupational health and safety is a holistic approach towards total well being of the employee at work. According to WHO (1995), occupational health includes the actions for occupational medicine, occupational hygiene, occupational psychology, safety, physiotherapy, ergonomics, rehabilitation, etc. Safety on the other side involves the protection of people from physical injury (Hughes et al, 2008). The International Occupational Hygiene Association (IOHA) generally defines occupational health and safety (OHS) as the science of anticipation, recognition, evaluation and control of hazards arising in or from the workplace that could impair the health and well-being of workers, taking into account the possible impact on the surrounding communities and the general environment (ILO, 2009). Thus, OHS can be seen to concern the promotion and maintenance of the highest degree of physical, mental and social well-being of workers in all occupations (ILO/WHO, 1995).

OHS thus transcend the common sense meaning of providing physical safety or physical well being. It encompasses two other equally important dimensions that make it a comprehensive system of work practice; mental well-being and psycho-social wellbeing. 
Occupational health and safety matters are particularly critical in the developing world especially Africa and Asia. Africa is especially beleaguered with unsafe working conditions in industries such as mining, construction, manufacturing and even service. Both continents are believed to have the most unsafe practices and conditions in the management of employment, child labour, the informal economy, gender mainstreaming, labour statistics, labour inspection and maritime safety, mining, HIV/AIDS and the world of work and international migration (Alli, 2008). Developing countries are therefore presented with enormous challenges in meeting the ILO codes of a sound occupational health and safety work environment (Alli, 2008). To establish the link between OHS and sustainable development, it will be important to understand the concept of sustainable development and how it is applied in this regard.

\section{Sustainable Development}

Sustainable development is the optimum use of resources in all respects. The Rio Summit (WHO, 1995) in its declaration defined sustainable development comprehensively as

“... a strategy to meet the needs of the present world population without causing adverse effect on health and on the environment, and without depleting or endangering the global resource base, hence without compromising the ability of future generations to meet their needs".

The above definition has two key concepts embedded within it. First the concept of 'needs', in particular the essential needs of the world's poor, to which overriding priority should be given; and the idea of limitations imposed by the state of technology and social organization on the environment's ability to meet present and future needs. Also, the definition places human beings at the centre of concept of sustainable development as individuals entitled to a healthy and productive life in harmony with nature. In sum, all life sustaining processes, production outcomes, and consumption endeavors should be sustainable.

Traditionally, sustainable development has assumed three main dimensions among development practitioners and researchers vis-à-vis; economic development, social development, and environmental protection. The United Nations 2005 World Summit outcome document refers to these as "interdependent and mutually reinforcing pillars". While this categorization does not seek to limit emerging dimensions of sustainable development, the focus is towards a workable framework that will consolidate the core objective of sustainability; "meeting the needs of the present without compromising the ability of future generations to meet their needs".

Although natural resources appear to have spurred the debate over sustainable development since the concept was first adopted in the Brundtland Report in 1987, a wider range of issues are currently contending their relevance in the definition of sustainable development. Quite recently, some indigenous people have argued, through various international forums such as the United Nations Permanent Forum on Indigenous Issues and the Convention on Biological Diversity, that there are four pillars of sustainable development, the fourth being culture. These current developments points to a future conceptual framework where sustainability can be argued to be part and parcel of every human endeavour.

\section{The Link between OHS and Sustainable Development}

While the present proposition of this paper does not seek to advance OHS as a competing pillar of sustainable development, current changes in the corporate mechanism, production processes and marketing strategies imposes new obligations on industry practitioners and policy makers to start thinking of how to harness the potentials of OHS in promoting sustainability. Despite improvements in work design, significant departures from work related hazards and occupational; diseases are still far from fruition. Thus occupational health and safety issues are still as relevant in today's work environments as yesterdays. In Ghana for instance, the absence of a comprehensive occupational health and safety policy makes this argument the more relevant. Despite the factories shops and offices Act of 1970, Workmen's compensation law Act 187 (1987), and Labour Act 651 (2003), all of which have snippets of regulations on OHS, occupational related accidents, diseases and hazards are estimated to cost Ghana about 7\% of her GDP (Adei $\&$ Kunfaa, 2004).

The astronomical cost of work related hazards and occupational diseases as reported by Adei and Kunfaa, (2004) is just not a matter of economic concern but that occupational health and safety of the working populace is a precondition for sustainable development (WHO 1995). Times have changed, and so have the responsibilities of leaders, whose accountabilities are no longer directed towards shareholders and the bottom line, but stakeholders and the environment. In addition making money is no longer enough; it is how the money is made that often comes under just as much scrutiny. 
It is important to make clear, two important propositions that the central theme of this paper is predicated upon. First the relationship between OHS and sustainable development does not dispute the Anglo-American corporate governance model where shareholders wealth maximization is the sole priority. On the contrary, sustainable development is critical in perpetuating the objects of shareholders wealth maximization. Secondly, sustainability is argued as a tool necessary to create a balance between shareholder expectation and stakeholder needs within a new paradigm of a balanced society (Kakabadse \& Kakabadse 2003).

Occupational health and safety and sustainable development can be approached from varying perspectives. In so far as sustainable development has been argued from various perspectives, the link between OHS and sustainable development can assume any of these varying perspectives. Based on a three pronged model of sustainability espoused by McKeown (2002), the role of OHS in promoting sustainable development can be argued in at least three dimensions; people, planet and profits. This framework has assumed various names in literature but it is commonly called the triple bottom line approach (Elkington, 1994). The difficulties in managing what is often regarded as competing elements in the wealth creation equation "people, planet and profit" is looked into in a recent article by Crews (2010) "Strategies for implementing sustainability: Five leadership strategies". Crews (2010) sought to provide ways for harnessing the potential that sustainable practices can offer.

The phrase "triple bottom line" was first coined in 1994 by John Elkington, the founder of a British consultancy called SustainAbility. His argument was that companies should be preparing three different (and quite separate) bottom lines. One is the traditional measure of corporate profit - the "bottom line" of the profit and loss account. The second is the bottom line of a company's "people account" - a measure in some shape or form of how socially responsible an organisation has been throughout its operations. The third is the bottom line of the company's "planet" account-a measure of how environmentally responsible it has been. The triple bottom line (TBL) thus consists of three Ps: profit, people and planet. It aims to measure the financial, social and environmental performance of the corporation over a period of time. Only a company that produces a TBL is taking account of the full cost involved in doing business (http://www.economist.com assessed 15-07-2011).

Profitability is considered as the prime driver of modern capitalist economies. Firms rely on sufficient profitability to meet shareholders needs of "value and wealth maximization". Although profitability and value maximization may mean different things when argued theoretically, the two are expected to move in tandem because profitability is a major and necessary condition and driver for maximizing the wealth of shareholders. In effect, firms cannot in practice achieve sustainability without meeting the profitability dimension of modern business concern. But how do firms achieve optimum profitability using all available opportunities and resources? Notice should be taken of the operational definition of "optimizing profitability". By optimizing profitability, firms should seek to make the best values out of all available opportunities and resources taking due recourse to alleviate all choices that stand the potential of wasting organisational resources. Will firms be considered as optimizing profitability in the face of significant occupational health and safety related diseases, accidents and hazards?

Globally, costs of occupational health and safety diseases have been on the increase. Global financial losses due to workplace injuries and ill health exceed $\$ 1,250$ billion (ILO, 2003). By conservative estimates workers suffer 270million occupational accidents and 160 million occupational diseases each year (ILO, 2006). Occupational injuries alone account for more than 10 million Disability-Adjusted Life Years (DALYs) lost, or healthy years of life lost whether to disability or premature death, and $8 \%$ of unintentional injuries worldwide (DCPP, 2007). Poor occupational health and reduced working capacity of workers may cause economic loss up to $10-20 \%$ of the Gross National Product of a country (WHO, 1995). Globally occupational deaths, diseases, and illnesses account for an estimated loss of $4 \%$ of the Gross Domestic Product (Takala, 2002).

A 2007/2008 survey by the HSE on work-related illness estimated 34 million lost work days; 28 million due to work related illness and 6 million due to workplace injury (HSE, 2009). Translating this in monetary terms means an erosion of a chunk of the profit margins of organisations. Jones et al., (1998) in a similar study reported that $14 \%$ of the people in the United Kingdom who retired early did so because of ill-health and part of these ill-health conditions were believed to be the result of working conditions or at least made worse by working conditions. A high standard of OHS correlates positively with high GNP per capita (WHO, 1995).

Indeed countries investing most in occupational health and safety show the highest productivity and strongest economies, while the countries with the lowest investment have the lowest productivity and the weakest economies (WHO, 1994). Thus, active input in occupational health and safety is associated with positive development of the economy, while low investment in occupational health and safety is a disadvantage in the economic competition. 
As pointed out earlier, Domestic statistics from Ghana shows that occupational health and safety related accidents, diseases and hazards cost Ghana about 7\% of her GDP (Adei \& Kunfaa, 2004). If these incidence of diseases and hazards are preventable or at least can be minimized; which in most instances are achievable, it can be assumed confidently that, globally or at national levels profitability is not being optimized. Thus prioritizing occupational health and safety issues are necessary to promote sustainability of businesses in themselves; where businesses here refers to either the global economy, National economies such as Ghana, and firms producing goods and services whether for profit or other business motives.

The second aspect of the tipple bottom line is "people". Willard (2002) categorizes the role of firms to "people" into two distinct and overlapping groups; internal employees and the rest of the world. To the internal employee, policy and efforts should be directed towards promoting respect for diversity and human rights; health and safety protection; empowerment and caring. To the rest of the world, Willard (2002) argues that, policy should be directed towards charitable contributions, corporate relations, closing gap between rich and poor. In summary, the "people" component of the TBL advances that employees need to be able to rely on a safe work environment that continuously reduces risk of injury. This is the basis for maintaining a sustainable workforce.

A sustainable workforce is intricately linked to businesses quest to optimize profitability. Compensation claims, employee turnover, industrial accidents arising out of disregard for occupational health and safety issues have serious impacts on profitability and shareholders wealth maximization. By and large, departures from occupational diseases and hazards are critical towards business sustainability.

Planet encompasses the environment and it encourages businesses to be eco-efficient. The environment stands by far the most singular arena that sustainable development literature appears to have been written on vigorously for the past two decades. The reason being that, the environment is intricately interwoven with every single human endeavour and that the sustainability of human species has so much to do with the environment.

When viewed within the context of sustainable development, environmental concerns become not just a cost of doing business, but a potent source of competitive advantage. Enterprises that embrace the concept effectively realize the advantages: more efficient processes, improvement in productivity, lower costs of compliance, and new strategic market opportunities" (Schmidheiny, 2002). Giving due attention to the "Planet" aspect of the TBL has important contribution towards the total well being of the employee and more importantly giving every firm a competitive edge.

\section{Discussion}

From the analysis of literature, OHS is also geared towards three pronged stakeholders; Economy, Environment and Society. The World economic Forum posits that the most competitive organizations are also the safest (World Economic Forum, 2002). In other words, organisations that practise the best OHS policies will achieve the best economy in their operations. Similarly, the best OHS practising firms repose the most optimum responsibilities they owe to society. Employees are part of society. The critical role every firm owes to society is keeping its employees safe- for they are part of society. Secondly, a safe and healthy employee is critical in combating civil society unrest arising out of poor and unsafe working conditions of today's civil society dynamics. Lastly, a sound OHS policy goes to the roots of environmental friendliness. It definitely makes no sense providing for the health and safety of employees while polluting the environment within which they reside with their families. An employee is part of the larger environment and stands the risk of contracting diseases at the cost of the firm and society. A sound OHS policy will embrace sufficient environmental friendly programmes to ensure that the employee is safe where ever he/she is. A safe employee outside the firm is a safe employee within the firm.

In Summary the three key benefits of OHS can be restated in the light of the TBL framework. Organizations with the best OHS policies are the most profitable (Economy); the most environmentally friendly (Planet) and they sever the best interest of society (People). The framework can be restated as, the best OHS practicing firms (Economy, Environment and Society) are the most sustainable (Profit, Planet, and People). The interface between OHS and sustainable development is shown in Figure 1 (See the 3P's).

\section{Conclusion}

Superior occupational health and safety policies are critical for sustainable development. They stand to bring in their wake superior intangible benefits ranging from improved environmental and social performance, higher employee job satisfaction and commitment, increased innovation and creativity and set a strong account for the triple bottom line of every entity.

There is a positive correlation between the protection of workers against occupational accidents, injuries, diseases physical and psychological overload and the prudent use of resources, minimizing the unnecessary loss of human and material resources. Occupational health and safety emphasizes best practices in the use of production technologies that ensures low energy usage, low emission and low waste technology which are key elements in sustaining the environment (WHO, 1995). 
In all, occupational health and safety practices provide a strategic management of the health, safety, working capacity and well-being of the working population who contribute significantly to the overall socioeconomic development of the country.

\section{References}

Adei, D., \& Kunfaa, E. Y. (2007). Occupational Health and safety policy in the operation of the Wood Processing industry in Kumasi, Ghana, 164. Journal of Science and Technology, 27(2),

Alli, B. O. (2008). Fundamental principles of occupational health and safety. International Labour Office, Geneva.

Amponsah-Tawiah, K., \& Dartey-Baah, K. (2011). Occupational Health and Safety in Ghana: Key Issues and Concrens. International Journal of Business and Social Science, 2(14), 119-126.

Bruntland, G. (ed.) (1987). Our common future: The World Commission on Environment and Development. Oxford, Oxford University Press.

Crews, D.E. (2010). Strategies for implementing sustainability: five leadership strategies. SAM Advanced Management Journal, 75(2), 15-21.

Do sustainable products require sustainable leaders? How managers can steer a course between people, profit and planet. (2011). Development and Learning in organisations, 25(2), 21-24. http://dx.doi.org/10.1108/14777281111108245

Hughes, P., \& Ferrelt, E. (2008). Introduction To Health And Safety In Construction Industry (3 ${ }^{\text {rd }}$ ed.). Butterworth-Heinemann, Imprint of Elsevier, USA, pp. 2-4.

International Labour Organisation. (2009). ILO Standards on Occupational Safety and Health: Promoting a safe and healthy working environment. International Labour Conference, 98th Session. Geneva.

Joint ILO/WHO Committee. (1995). Definition of Occupational and Safety. $12^{\text {th }}$ Session of Joint ILO/WHO Committee on Occupational Health. [Online] Available: www.ilo.org/safework

Kakabadse N. K., \& Kakabadse A. (2003). polylogue as a platform for governance: Integrating people, the planet, profit and posterity. Journal of corporate governance, 3(1).

McKeown R. (2002). Education for sustainable development toolkit. Portland State University. [Online] Available: http://www.esdtoolkit.org/ (5/07/11)

Schmidheiny, S. (2002). Walking the Talk: the Business Case for sustainable development. Greenleaf publishing limited, United Kingdom.

Takala, J. (2002). Safe work - the global program on safety, health and the environment. Asian-Pacific Newsletter on Occupational Health and Safety, 7, 4-8.

The World Economic Forum Annual Report. (2002). [Online] Available: http://www.Scribid.com/doc/6293577/world-economic-forum-annual-report-20022003

WHO. (1995). Global strategy on occupational health for all: The way to health at work. Geneva.

Willard, B. (2002). The Sustainability Advantage: Seven Business Case Benefits of a Triple Bottom Line. New Society Publishers.

Zwetsloot G.I.J.M., \&A. Starren. (2004). Corporate Social Responsibility and Safety and Health at Work. Research Report from the European Agency for Safety and Health at Work, Issue 210, Bilbao, 131 pages.

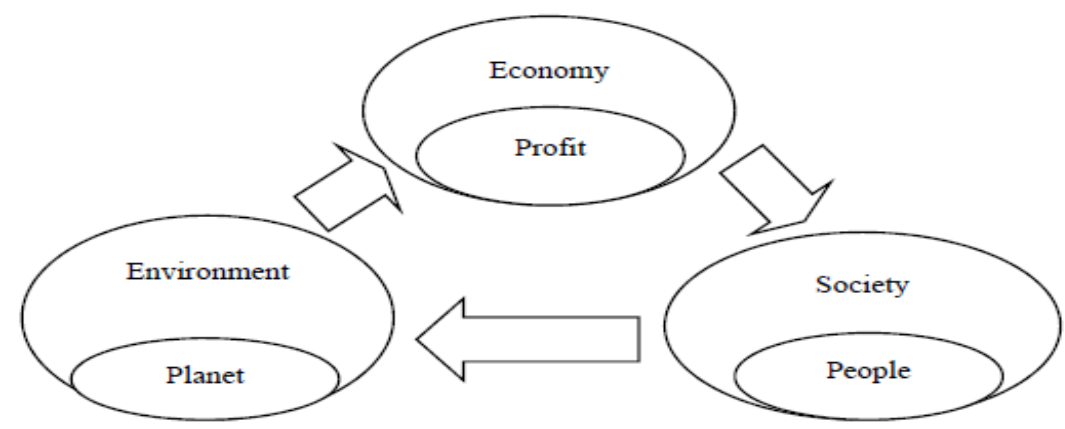

Figure 1. OHS sustainable development interface (See the 3P's) 